\title{
Security forecasts of terrorist attack
}

\author{
Marta Blahova* \\ Tomas Bata University in Zlín, Nad Stráněmi 4511, 76005 Zlín, Czech Republic
}

\begin{abstract}
This article deals with security developments in terrorism. In the introductory part, the article deals with the history and current situation of terrorism. Furthermore, the national ones are analyzed and International Security Strategy Papers on Counter-Terrorism. In the next part of this article, long-term safety forecasts from the Czech Republic are analyzed and foreign authors with a focus on terrorism. The main outcome of the article is a proposal for an alternative scenario of possible security developments in the area of terrorism within the European Union.
\end{abstract}

\section{Introducion}

Human society has been exposed to terrorism for centuries, although its current form has changed somewhat with time and technology. The extent and damage, forms and methods that many states today, not just Western countries, are confronted with are increasingly cruel. But what can be expected in the future? Will it change again or will it be eliminated? In particular, this work deals with these and other issues concerning the development of terrorism not only in the EU but also in the world.Helping to find answers to these questions can help us in the field of futurology, the science of future research. However, predicting the future and the more so in the field of security development has some pitfalls as it is a dynamically changing area and this complicates the forecasting process. The importance of anticipating the future lies first and foremost in preparing governments and policy for potential problems that will need to be addressed, and that means preparing for future challenges that may arise.

\section{Terrorism issues}

Promoting one's own interests in the form of violence is basically as old as humanity itself. So it can be said that in a sense people have been dealing with terrorism from the very beginning. But with the development of human society and the development of technology, the modus operandi of terrorists is changing. But the trend in the development of terrorism is influenced by the status of a particular society. If social, political, and economic tensions are growing, the number of terrorist acts is increasing, otherwise terrorist activity is decreasing as society becomes more stable. A few decades ago, the terrorist attack on society or the region was only a threat, and today such a manifestation of violence can cause political or economic instability in global dimensions, leading to uncontrolled developments in future events [1]. In addition to organized crime, extremism, religious, national and social conflicts, the integration of migrants into mainstream society and economic or environmental risks, the issue of terrorism remains one of the most important security issues today [2].

\subsection{Historical development of terrorism}

It might seem that terrorism is a modern instrument, but the opposite is true. This subject is continually inflected in human history. If one party gave the impression that by causing fear it would force the other to subordinate it, without hesitation it was not afraid to use such behavior. At the time of antiquity, the application of violence often did not include all the aspects that characterize terrorism in the modern world. Many examples of anti-terrorist violence that could now be broadly related to the concept of terrorism are more similar to the understanding of terror as a policy tool [3].

Terrorist acts are also evidenced by historic sources, be it Egyptian hieroglyphic texts, the Bible or Homer's Odyssey [1]. The Book of Joshua states, "The Israelites have smitten all living things with the edges of their swords in the city of Jericho; men and women, old and young, oxen, sheepIn this way, wars were typically conducted at that time, and in many other centuries, when the city was conquered after a long siege and effort to defend the city and slaughtered all its inhabitants. This meeting was supposed to cause fear in the neighboring towns, which were to be later

*Corresponding author: m6_blahova@utb.cz 
exposed to similar behavior. The physical destruction of political opponents or potential opponents in history can often be perceived, including the history of our country. Although violence in peacetime has always been described as an immoral instrument, not only has it been a political goal, has it not been an obstacle to its application [3].

\section{Current long-term security forecast}

In this part is made analysis and description of security forecasts from Czech and foreign authors. The forecasts are focused on the future security situation in the world until 2050.

\subsection{The forecast of political, economic and security developments in the world between 2020 and 2025}

According to Miloš Balabán, the eminent German sociologist Ulrich Beck described the trend of the 21st century world, whose main features were the threat of ecological crisis, the global financial crisis and the threat of terrorism. The lecture at the London School of Economics and Political Science, where he presented these features of the company, took place in 2002, but Beck's conclusions are basically up to date and can serve as a valuable framework for our reflection on potential, without doubt future. The prognosis is divided into two parts, where in the first part the main trends in the world by 2025, in the second part, the basic contours of the development of the Islamic world are discussed. In the forecast, the author states that security issues will be by 2020 one of the world's leading political agendas. According to the 2003 European Security Strategy, terrorism, the proliferation of weapons of mass destruction, regional conflicts, the existence of failed states and organized crime will continue to be the primary threats. This list of threats will be extended by a number of others where it may happen to disrupt economic, energy, cyber and biosafety, and the existence of "collapsed" cities will be a security threat alongside the collapsed states.

From a geographical point of view, many security threats, along with Islamist terrorism, will come from the so-called instability arch: sub-Saharan Africa (North and East Africa) - Middle East - Balkans Caucasus - Central Asia - Southeast Asia. Potential conflicts from "arc of instability" will also multiply other potential areas of security instability, such as tense Israeli-Palestinian relations, Indian-Pakistani dispute over Kashmir, or tensions between Taiwan and China and the Korean Peninsula (possible use of nuclear weapons by the DPRK and possible consequences of the collapse of the totalitarian regime in that country). The proliferation of weapons of mass destruction (WMD) and nuclear weapons will be a risk. At the beginning of the 21 st century, it was revealed that a contracted regime of nuclear non-proliferation that works since the 1970 s, does not correspond to the development of new technologies and the process of globalization. Indeed, the illegal trade in nuclear materials and know-how of nuclear weapons has in fact been out of control, with the result that more and more countries have become available to nuclear weapons or technologies to produce them, even in risky areas (Near East, East Asia).

Beyond nuclear weapons, an increase in the importance of chemical and biological weapons, which can also be gained through the development of their commercial production, can be expected. Against this background, chemicals that will be difficult to recognize will be the terrorists' viewfinder. At the same time, biological weapons form a serious threat for the future and for the future. A potential bioterrorist attack would represent impacts that would spread rapidly on a global scale. The world can also face other security threats: the abuse of nanotechnology. The real possibility becomes the use of knowledge-enabled mass destruction (KMD). It is perhaps only a matter of time before nanotechnology comes to the attention of terrorist organizations when it is already part of the development of modern weapons [4].

\subsection{Security situation in 2020 with a view to 2050}

The forecast by leading Czech author Antonín Rašek, who has been awarded many prizes for his literary work, describes the security environment in the world between 2020 and 2050 .

In 2020, the possible conflicts that arise from insufficient socio-cultural adaptation of people under pressure outside European cultures are predicted. and ways of life, if the ambitious European integration project fails. Pandemics may also be a danger. The technological maturity of the integrated "security cloak" in the developed countries of the northern part of the Earth and certain countries in the southern part of the planet will make it impossible for terrorism or organized violence to be more active, but it will not prevent the penetration of terrorist-criminal-economicideological networks into a guarded area [5]. Around the twenties of the 21 st century, they will be at a very high level of quality and prepare European collective rapid reaction forces. Between 2025 and 2045, these forces will almost always operate in deployments in the Mediterranean mainly due to influence migration. In the 1930s, chips will be used to monitor potential people, both local and foreign, through chips. In the EU, the program will be launched with the intention of identifying the people connected by the chip terrorist organizations and all visitors from risky countries. As a result of a terrorist attack from one of the EU Member States, under Article 5, NATO is carrying out an operation - a blockade and a partial invasion of one of the Islamic countries, a base of attackers. The threats caused by mass migration will not be resisted, the overwhelming majority of the measures will be of a reactive nature, and quite passive.

*Corresponding author: m6_blahova@utb.cz 
As a tool against security threats, it will be used:

- Integration of data systems

- Preventive optional strikes by new technologies

- Covering space with effective defense systems

- Reinforcement of "sanitary cordons" and possible pandemics.

The attack on New York is marked by terrorists as the main actor in the security threat. Terrorism as a way of fighting is and has been known in the past. However, it has never reached the level of power, organization and sophistication as it did at the beginning of this century. Unfortunately, the cruelty, the number of victims, and the deliberate choice of goals. The Rise of Terrorist Activities in the Second Decade, and Above all, the American Solution of the Supportive Position of Strong States such as Russia, Japan, and New China Powers, India and the rest of the pro-American thinking of the Arab and Islamic states, who will also feel threatened by fundamentalism, will enforce a counter-terrorism alliance directed towards ultimate clearing. In this final fight, terrorists implement all the means, including WMD, and no country is spared, including the Czech Republic. Civilized countries use all instruments from a drastic reduction in the freedoms and rights of citizens, to the division and choice of races and nationalities, after deploying the army and occupying critical territories. However, they do not even use WMD retaliation. Their terrorist abuse is spontaneously condemned, which will fundamentally help to eliminate the terrorist movement around the world along with outbreaks in the Middle East. In the long term, around 2050, a comprehensive approach to preventive solutions to security threats will be enforced. A common foreign and security policy will be achieved in Europe, leading to the gradual integration of national security systems, even if this happens gradually and in stages. The response rate will be adequate to the development of a global security environment. Integration trends between Europe, the US, Russia, the completion of a coordinated defense system and the creation of relations will be strengthened. with power formations around India [5].

\section{The future of "anonymous" attractors and weapons of low destruction}

Terrorism will turn into something more tactically more acceptable by all types of actors by 2025 and it does not have to be those who appear today. Dissemination of technologies, know-how, weapons of mass destruction, explosive devices and drones are examples of tactics and techniques that will be more readily available to a wider range of terrorist groups, "lone wolves" or criminal organizations. The threat of Al-Qaeda attacks will gradually decrease over the years, but will not completely disappear, and by 2022 , the organization will attempt to launch a dirty bomb [4].

Most security threats along with Islamist terrorism will be directed North and East Africa, the Middle East, the Balkans, the Caucasus and the Middle and Southeast Asia. Attacks from these areas will be intensified by the intensified relations between Israel and Palestine, the conflict between India and Pakistan about Kashmir and the intensified relations of Taiwan with China and the Korean Peninsula [4].

China's continuous high level of economic growth by 2020 will allow the US to spend the same amount of resources on its military, making China a genuine power, resilient to any threat. In a few years, they will grow due to technical development and increasing with asymmetry between forces, threat of nuclear weapons and weapons of mass destruction In the second half of the twenties, the world will face a new threat, which is potential abuse of nanotechnology, where nanorobots, a remote control, with the potential to spread a highly contagious virus are forms. By increasing the development of cyber attacks, precisely controlled weapons, robotic systems and unmanned weapons, the threshold to implement the conflict will be reduced.

Since North Korea will threaten a nuclear attack and there will be uncertainty about Iran's intentions, some states will tend to own a similar weaponry arsenal. Not only armaments with nuclear weapons, but increased importance will be attached chemical and biological weapons. China and Russia will continue to use weapon systems that will be able to destroy satellites in orbit. By 2035, the threat of terrorism will be a primary concern for European policy makers. Given the fact that online recruitment of new members and the incitement of attacks by "lone wolves" will not require large and vulnerable networks that governments might disrupt, this will remain until this year [5].

People will increasingly perceive danger from Russia, the threat of Islamic extremism and the continuing arrival of threats from the Middle East and Africa. Russia will threaten Europe with propaganda, disinformation and financial support for parties against the EU and the US. Security forces will not be tracking and detecting all potential terrorists in Europe, mainly because of the collapse of the Islamic state in Sirius and Iraq, which will cause the return of foreign fighters. For security forces it will be very difficult to prevent attacks from those who will be inspired by the very attractive nature of the "lone wolves" attacks that have taken place in recent years. Terrorist action against soft targets will persist as a permanent threat in Europe, including traditional species and sources of terrorism. Due to the interest of large powers, the constant threat of terrorism, the fragile situation in weak states and the spread of lethal technologies, the risk of conflict will increase. Influence of technology, new stratégy and the evolving global geopolitical

*Corresponding author: m6_blahova@utb.cz 
context will result in a change in the character of the conflict. In particular, the aim will be to reduce the cost of potential terrorist action. There will be a proliferation of automated systems and those with weapon potential [7].

In support of its activities, non-state and sub-state groups, along with terrorists, insurgents, activists and criminal gangs, will join a wider range of lethal and non-lethal tools. Over the past decade, Hezbollah and ISIL will gain access to complex anti-tank missiles, ground-to-air missiles, unmanned aerial vehicles, and a number of other precisely controlled missiles that will become more common. Hostile state and non-state actors will intend to cause massive losses lives towards goals such as government officials and soft targets, especially places with a high population and places of symbolic importance, and will therefore seek access and use of CBRN weapons or new technologies based on weapons of mass destruction. The current states will have a nuclear arsenal and will maintain and modernize these weapons. Synthetic biological components can lead to new pathogens that can be produced and released intentionally or by chance. There will be a risk of a large-scale cyber attack the subsequent manipulation of the information obtained, leading to major physical, emotional or financial implications [7].

\section{Discussion}

Through the 2001 New York terrorist actions, terrorism has reached a global level, and their modus operandi has changed, the way attacks are being targeted since these events, which took place nearly 20 years ago, are aimed at vulnerabilities, especially at insufficiently protected places with a high concentration of people. Thus, today's human society is facing attacks that, by their nature, threaten a person's life almost anywhere, whether it is a quiet café in the middle of a city or a sporting event. Certainly, however, many people will wonder if this trend will continue or the nature of terrorism will change in the future?

Futurology is a science that not only provides a glimpse into the future of government officials, so that they can take a look at future developments and direct their influence and capacity to the right security spots to at least mitigate the impact of potential events on human beings. company.

Acknowledgments:This research was based on the support of the Internal Grant Agency of Tomas Bata University in Zlín, the IGA / FAI / 2019/003 project and the Institute of Safety Engineering, Faculty of Applied Informatics.

\section{References}

1. M., BRZYBOHATÝ, T. (1999)

2. The Czech Republic's Strategy for Combating Terrorism since (2013)

3. Svojtka \& Co., (2001)

4. E., SOULEIMANOV, M., BELFER. Taaeau (2010).

5. O., MIKA, CM (2003)

6. Ministry of the Interior of the Czech Republic: Typologie terorismu (2018)

7. Z., KALVACH, SM

*Corresponding author: m6_blahova@utb.cz 